HORTSCIENCE 28(1):35-37. 1993.

\section{Drip-irrigation Scheduling for Fresh-market Tomato Production}

\author{
T.K. Hartz \\ Department of Vegetable Crops, University of California, Davis, CA 95616
}

Additional index words. evapotranspiration, crop coefficient, Lycopersicon esculentum

\begin{abstract}
Drip-irrigation scheduling techniques for fresh-market tomato (Lycopersicon esculentum Mill.) production were compared in three growing seasons (1989-91). Three

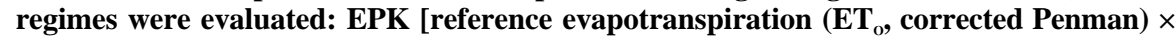
programmed crop coefficients], ECC $\left(\right.$ ET $_{0} \times$ a crop coefficient based on estimated percent canopy coverage), and SMD (irrigation at $20 \%$ available soil moisture depletion). EPK coefficients ranged from 0.2 (crop establishment) to 1.1 (full canopy development). Percent canopy coverage was estimated from average canopy width $\div$ row width. Irrigation in the SMD treatment was initiated at $-24 \mathrm{kPa}$ soil matric tension, with recharge limited to $80 \%$

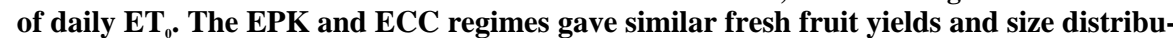
tions in all years. With the EPK scheduling technique, there was no difference in crop response between daily irrigation and irrigation three times per week. In all seasons, ECC scheduling resulted in less total water applied than EPK scheduling and averaged $76 \%$ of seasonal $\mathrm{ET}_{0}$ vs. $86 \%$ for EPK. Irrigating at $20 \%$ SMD required an average of only $64 \%$ of seasonal $\mathrm{ET}_{0}$; marketable yield was equal to the other scheduling techniques in 1989 and 1991, but showed a modest yield reduction in 1990. Using an SMD regime to schedule early season irrigation and an ECC system to guide application from mid-season to harvest may be the most appropriate approach for maximizing water-use efficiency and crop productivity.
\end{abstract}

Recently, drip-irrigation use has increased rapidly in the California tomato industry. Currently, $>50 \%$ of fresh-market tomato acreage in the state is drip-irrigated. Major reasons for this conversion from furrow irrigation are improved water application efficiency and precision placement with drip irrigation. These features increase efficient agricultural water use and minimize nitrate leaching.

Received for publication 16 Mar. 1992. Accepted for publication 3 Sept. 1992. The cost of publishing this paper was defrayed in part by the payment of page charges. Under postal regulations, this paper must therefore be hereby marked advertisement solely to indicate this fact.

HortSCIENCE, Vol. 28(1), JANUARY 1993
1977) J. Russo (1983) found that daily irrigation is required for maximum tomato yields, while Meek et al. (1983) and Hutmacher et al. (1985) found that daily irrigation gives yields similar to those achieved with longer intervals. These variable results were due largely to many site-specific factors involved in crop response, including bed configuration, crop vigor, soil fertility, soil and water salinity, and $\mathrm{ET}_{0}$ estimation method. Appropriately applying crop coefficients (numericalconstants that relate relative water demand to crop growth stage) is also important. These factors are seldom explained in sufficient detail. Also, studies comparing drip-irrigation regimes commonly compare grossly dissimilar treatments [e.g., $35 \%, 70 \%$, or $105 \%$ of Class A pan evaporation (Sanders et al., 1989)], thus leaving considerable question with regard to optimal irrigation regime. The present work compared the water-use efficiency (WUE) and crop productivity of various drip-irrigation scheduling techniques to provide a better understanding of optimal drip-irrigation management for commercial fresh-market tomato production.

Field studies were conducted during three consecutive years (1989-91) at the Univ. of California South Coast Field Station in Irvine. The soil was a San Emigdio sandy loam [mixed (calcareous), thermic Typic Xerofluvent] with a bulk density of $1.5 \mathrm{~g} \cdot \mathrm{cm}^{-3}$ and $11 \%(\mathrm{v} / \mathrm{v})$ available moisture (field capacity to-1.5 $\mathrm{MPa}$ ) in the top $45 \mathrm{~cm}$. Soil matric potential and soil moisture content at field capacity were determined by irrigating the field before planting, and covering three representative sites with polyethylene film to minimize evaporation. Four tensiometers were placed $30 \mathrm{~cm}$ deep at each site and read daily until equilibrium was established, at which time gravimetric soil moisture levels were determined on samples of the top $45 \mathrm{~cm}$. The lower limit of soil water availability was estimated by $-1.5 \mathrm{MPa}$ pressure-plate determinations on intact soil cores.

In all three seasons, the soil was tilled into raised 1-m-wide beds on 1.5-m centers. A 
single drip-irrigation line (Turbo-tape, 20-cm emitter spacing, T-Systems, San Diego) was buried $15 \mathrm{~cm}$ deep in the center of each bed. Preplant fertilizer was banded in each bed at $55 \mathrm{~kg} \mathrm{~N}$ and $30 \mathrm{~kg} \mathrm{P} / \mathrm{ha}$. 'Bingo' tomato transplants were set in the field on 3 Apr. 1989, 26 Apr. 1990, and 19 Apr. 1991, respectively. After allowing 3 weeks for transplant establishment, irrigation treatments were initiated. The design was a randomized complete block with four single-bed replications. Individual plots were $15 \mathrm{~m}$ long $\times 1.5 \mathrm{~m}$ wide, with a plant spacing of $0.4 \mathrm{~m}$

Three irrigation-scheduling techniques were evaluated: $\mathrm{EPK}\left(\mathrm{ET}_{0} \times\right.$ programmed crop coefficients), ECC (ET $\times$ a crop coefficient based on estimated percent crop canopy coverage), and SMD irrigation initiated at $20 \%$ available soil moisture depletion. $\mathrm{ET}_{0}$ values used in this study were generated by the California Irrigation Management and Information Systems (Pruitt et al., 1987); $\mathrm{ET}_{0}$ was calculated by a modified Penman equation from hourly weather data (Pruitt and Doorenbos, 1977). Programmed crop coefficients designed to account for crop growth stage, adapted from Snyder et al. (1987), were 0.2 for the establishment phase and rose to 1.1 at maximum canopy development. For the EPK scheduling method, irrigation was delivered three times per week in all seasons. Additionally, a daily EPK treatment was included in 1990 and 1991. For the ECC scheduling method, percent crop canopy coverage was estimated by dividing the average canopy width by the row width $(1.5 \mathrm{~m})$; irrigation was applied three times per week. For the SMD scheduling method, irrigation was initiated at $-24 \mathrm{kPa}$ soil matric potential as measured at a $30-\mathrm{cm}$ depth by tensiometers. Application volume during canopy development was 4.0 $\mathrm{mm}, \approx 80 \%$ of historical mid-season daily $\mathrm{ET}_{0}$. When full crop canopy developed, applications were increased as required to maintain delivery at $80 \%$ of real-time $\mathrm{ET}_{0}$.

Tensiometers extending 30 and $45 \mathrm{~cm}$ deep were installed $15 \mathrm{~cm}$ from the plant row in all plots to monitor soil matric potential $\left(\mathrm{Y}_{\mathrm{m}}\right)$ daily. Additional $\mathrm{N}$ was delivered through the drip system in eight weekly $15-\mathrm{kg} \cdot \mathrm{ha}^{-1}$ applications for a total of $175 \mathrm{~kg} \cdot \mathrm{ha}^{-1}$. Routine pestcontrol practices were followed. Pink fruit were harvested weekly (three times in 1989, twice in 1990 and 1991) followed by a final harvest of pink and mature-green fruit. Fruit from $6 \mathrm{~m}$ per plot were harvested in 1989, and fruit from $8 \mathrm{~m}$ per plot were harvested in 1990 and 1991. Marketable fruit were categorized by size: $>7.0 \mathrm{~cm}$ in diameter [encompassing U.S. Dept. of Agriculture (USDA) size designation "extra large"] and 5.7 to $7.0 \mathrm{~cm}$ (USDA designations "medium" and "large"). Fruit $<5.7 \mathrm{~cm}$ in diameter were considered unmarketable. Once harvest began, the various irrigation treatments ended and all plots received a daily application equal to $80 \% \mathrm{ET}_{0}$. At the beginning and the end of the 1989 and 1990 seasons, composite soil samples from 5 to 75 $\mathrm{cm}$ deep of the entire raised bed width were analyzed for electrical conductivity to deter- mine the effects of irrigation practices on rootzone soluble salt concentration.

There was no difference in any season between EPK or ECC irrigation regimes with respect to total or marketable tomato fruit fresh weight or fruit size distribution (Table 1); fruit yields and the percentage of large fruit were considerably higher than commonly attained in commercial production. Irrigation frequency did not affect fruit yield in any year. In the 1991 study, irrigation in excess of EPK $(1.25 \times \mathrm{EPK})$ significantly reduced total and marketable fruit yield relative to EPK. Compared to the other irrigation regimes, SMDbased scheduling modestly reduced total and marketable fruit yield in 1990 and, compared to EPK scheduling, produced fewer large fruit in 1989. Cull fruit production differed among treatments only in 1991, during which the more conservative scheduling treatments (SMD and ECC) produced less cull fruit weight. Treatment did not affect the incidence of fruit showing blossom-end rot or other water stressrelated defects in any year.

Total seasonal $\mathrm{ET}_{0}$ ranged from 350 to 410 $\mathrm{mm}$ in the three years (Table 2). There was significant precipitation only in 1990, when $15 \mathrm{~mm}$ was recorded. Total applied water (irrigation plus precipitation) was highest for the EPK treatment across the study seasons. Across the three study seasons, WUE, defined

Table 1. Influence of irrigation regime on tomato fruit yield and size distribution.

\begin{tabular}{|c|c|c|c|c|c|c|}
\hline \multirow[b]{2}{*}{ Season } & \multirow{2}{*}{$\begin{array}{c}\text { Irrigation } \\
\text { regime }\end{array}$} & \multicolumn{3}{|c|}{ Fruit yield (kg/plot) } & \multicolumn{2}{|c|}{ Fruit size $(\%)^{x}$} \\
\hline & & Total & Marketable & Cull & Large & Medium \\
\hline \multirow[t]{4}{*}{1989} & EPK & 96.2 & 75.3 & 20.9 & $58 \mathrm{ab}$ & 42 \\
\hline & $\mathrm{ECC}$ & 88.1 & 70.0 & 18.1 & $64 \mathrm{a}$ & 36 \\
\hline & SMD & 94.2 & 74.5 & 19.7 & $55 \mathrm{~b}$ & 45 \\
\hline & & NS & NS & NS & & NS \\
\hline \multirow[t]{5}{*}{1990} & EPK & $148 \mathrm{a}$ & $132 \mathrm{a}$ & 16.1 & 73 & 27 \\
\hline & EPK (daily) & $155 \mathrm{a}$ & $137 \mathrm{a}$ & 18.4 & 72 & 28 \\
\hline & $\mathrm{ECC}$ & $155 \mathrm{a}$ & $136 \mathrm{a}$ & 18.1 & 68 & 32 \\
\hline & SMD & $131 \mathrm{~b}$ & $112 \mathrm{~b}$ & 19.5 & 68 & 32 \\
\hline & & & & NS & NS & NS \\
\hline \multirow[t]{6}{*}{1991} & EPK & $183 \mathrm{a}$ & $164 \mathrm{a}$ & $18.4 \mathrm{a}$ & 82 & 18 \\
\hline & EPK (daily) & $169 \mathrm{ab}$ & $148 \mathrm{ab}$ & $20.5 \mathrm{a}$ & 86 & 14 \\
\hline & $\mathrm{EPK} \times 1.25$ & $154 \mathrm{~b}$ & $137 \mathrm{~b}$ & $16.8 \mathrm{ab}$ & 82 & 18 \\
\hline & $\mathrm{ECC}$ & $163 \mathrm{ab}$ & $150 \mathrm{ab}$ & $13.6 \mathrm{~b}$ & 80 & 20 \\
\hline & $\mathrm{SMD}$ & $169 \mathrm{ab}$ & $163 \mathrm{a}$ & $6.4 c$ & 81 & 19 \\
\hline & & & & & NS & NS \\
\hline
\end{tabular}

${ }^{z}$ Analyses performed on arcsin-transformed data.

${ }^{\mathrm{y}} \mathrm{EPK}=\mathrm{ET}_{\mathrm{o}} \times$ programmed crop coefficient $; \mathrm{ECC}=\mathrm{ET}_{\mathrm{o}} \times$ percent canopy coverage $; \mathrm{SMD}=$ irrigation at $20 \%$ available soil moisture depletion.

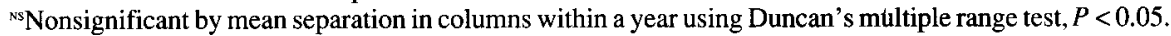

Table 2. Irrigation amount and water-use efficiency (WUE) for 1989-91 as influenced by irrigation regime in tomato fruit production.

\begin{tabular}{|c|c|c|c|c|c|}
\hline \multirow{2}{*}{$\begin{array}{l}\text { Irrigation } \\
\text { regime }^{\mathrm{x}}\end{array}$} & \multicolumn{3}{|c|}{ Total water $^{2}(\mathrm{~mm})$} & \multirow{2}{*}{$\begin{array}{c}\text { WUE }^{y} \\
\left(\mathrm{t} \cdot \mathrm{ha}^{-1} \cdot \mathrm{mm}^{-1}\right)\end{array}$} & \multirow[b]{2}{*}{$\%$ Seasonal ET ${ }^{w}$} \\
\hline & $\overline{1989}$ & 1990 & 1991 & & \\
\hline EPK & 307 & 345 & 318 & 0.33 & 86 \\
\hline $\mathrm{ECC}$ & 249 & 328 & 290 & 0.36 & 76 \\
\hline SMD & 216 & 264 & 249 & 0.42 & 64 \\
\hline Seasonal ET & 363 & 414 & 356 & & \\
\hline
\end{tabular}

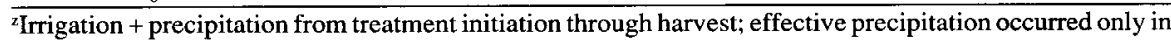
1990 , for a total of $15 \mathrm{~mm}$.

${ }^{y}$ WUE, tonne marketable fruit/ha per millimeter total water (irrigation + precipitation); mean of 1989-91 seasons.

${ }^{x} \mathrm{EPK}=\mathrm{ET}_{\mathrm{o}} \times$ programmed crop coefficient, $\mathrm{ECC}=\mathrm{ET}_{\mathrm{o}} \times$ percent canopy coverage, and SMD $=$ irrigation at $20 \%$ available soil moisture depletion.

wTotal water/seasonal ET. 
quality, low initial soil conductivity and modest water demand kept root-zone salinity buildup from being a significant factor in any treatment.

EPK and ECC irrigation scheduling resulted in similar total and marketable tomato yields and fruit size distributions in all seasons. Prior knowledge of crop phenology at this site and a row configuration that gave complete canopy coverage allowed the efficient use of a predetermined crop coefficient system. However, slower-than-expected crop canopy development in 1989 resulted in early season EPK irrigation considerably above that required by ECC scheduling. This result emphasizes the potential inefficiency of programmed coefficients. ECC scheduling, which related irrigation volume directly to crop vigor, functioned well in all seasons. The method used to determine canopy cover was simple, quick, and easily adopted by commercial growers. The importance of accounting for crop growth stage when estimating tomato irrigation requirements was illustrated by Smajstrla and Locascio (1990), who compared drip irrigation initiated at -10 or $-15 \mathrm{kPa}$ with a daily application of 0.5 Class A pan evaporation $\left(\mathrm{E}_{\mathrm{pan}}\right)$ without adjusting for crop growth stage. In 2 years of study, using nonamended $\mathrm{E}_{\mathrm{pan}}$ resulted in significant overirrigation in the early season until a mature plant canopy was developed.

Both EPK and ECC regimes, with maximum coefficients of 1.1 and 1.0, respectively, maintained soil matric potential near field capacity. These results agree with those of Phene et al. (1985), who found that evapotranspirational losses of drip-irrigated tomatoes peaked at $\approx 1.05 \times \mathrm{ET}_{0}$. The $\mathrm{ET}_{0}$ estimate used in both studies was relatively conservative, $\approx 80 \%$ of Class A pan evaporation values. Irrigating in excess of the EPK scheduling technique $(\mathrm{EPK} \times 1.25)$ actually decreased tomato fresh fruit weight in 1991. Locascio et al. (1990) also reported decreasing tomato yield and fruit size with increasing irrigation above crop requirements; the yield depression may have been related to increased leaching loss of applied $\mathrm{N}$.

In this study, irrigation frequency (daily or three times per week in 1990 and 1991 for EPK treatments) did not affect crop response. Actual soil moisture depletion in the root zone with irrigation three times per week was generally $<25 \%$ of available soil moisture. Under different soil and climatic conditions, daily irrigation may be advantageous, but may have negative consequences as well. Meek et al. (1983) showed that daily drip irrigation can reduce soil $\mathrm{O}_{2}$ to low, potentially damaging levels. Phene et al. (1985) and Davis et al. (1985) advocated multiple irrigations per day, with irrigation delivered with each $1 \mathrm{~mm}$ of accrued estimated evapotranspiration. Locascio et al. (1989), however, found no advantage to multiple applications per day for tomato production.

SMD scheduling reduced water application substantially, because application was limited to $80 \%$ of daily ET at full canopy and less water was applied during canopy development. Although clearly a deficit irrigation treatment, the diminution of fruit yield was modest and resulted in high WUE. In areas of restricted water availability or high water cost, SMD scheduling may have merit. Using soil moisture depletion to schedule early season irrigation and an ECC system to guide application from mid-season to harvest may be the most appropriate approach for commercial growers.

\section{Literature Cited}

Bar-Yosef, B. and B. Sagiv. 1982. Response of tomatoes to $\mathrm{N}$ and water applied via a trickle irrigation system. II. Water. Agron. J. 74:637639.

Davis, K.R., C.J. Phene, R.L. McCormick, R.B. Hutmacher, and D.W. Meek. 1985. Trickle irrigation frequency and installation depth effects on tomatoes. Proc. Third Intl. Drip/Trickle Irrig. Congr., Fresno, Calif. p. 896-902.
Doorenbos, J. and W.O. Pruitt. 1977. Crop water requirements. Irrigation and Drainage Paper 24. Food and Agricultural Organization, Rome.

Hutmacher, R.B., S.S. Vail, J.G. Muthamia, V. Mwaja, and R.C. Liu. 1985. Effect of trickle irrigation frequency and installation depth on tomato growth and water status. Proc. Third Intl. Drip/Trickle Irrig. Congr., Fresno, Calif. p. 798804.

Locascio, S.J., S.M. Olson, and F.M. Rhoades. 1989. Water quantity and time of $\mathrm{N}$ and $\mathrm{K}$ application for trickle irrigated tomatoes. J. Amer. Soc. Hort. Sci. 114:265-268.

Locascio, S.J., S.M. Olson, F.M. Rhoades, C.D. Stanley, and A.A. Csizinszky. 1985. Water and fertilizer timing for trickle-irrigated tomatoes. Proc. Fla. State Hort. Soc. 98:237-239.

Meek, B.D., C.F. Ehlig, L.H. Stolzy, and L.E. Graham. 1983. Furrow and trickle irrigation: Effects on soil oxygen and ethylene and tomato yield. Soil Sci. Soc. Amer. J. 47:631-635.

Phene, C.J., R.L. McCormick, J.M. Miyamoto, D.W. Meek, and K.R. Davis. 1985. Evapotranspiration and crop coefficient of trickle-irrigated tomatoes. Proc. Third Intl. Drip/Trickle Irrig. Congr., Fresno, Calif. p. 823-831.

Pruitt, W.D. and J. Doorenbos. 1977. Empirical calibration a requisite for evapotranspiration formulae based on daily or longer mean climatic data. Intl. Conf. Evapotranspiration, Budapest, Hungary, 26-28 May.

Pruitt, W.D., E. Fereres, and R.L. Snyder. 1987. Reference evapotranspiration ( $\mathrm{ET}_{\mathrm{o}}$ ) for California. Univ. of Calif. Coop. Ext. Bul. 1922.

Russo, D. 1983. Crop yield-irrigation relationships in a gypsiferous-sodic soil. Agron. J. 75:427434

Sanders, D.C., T.A. Howell, M.M.S. Hile, L. Hodges, D. Meek, and C.J. Phene. 1989. Yield and quality of processing tomatoes in response to irrigation rate and schedule. J. Amer. Soc. Hort. Sci. 114:904-908.

Smajstrla, A.G. and S.J. Locascio. 1990. Irrigation scheduling of drip-irrigated tomato using tensiometers and pan evaporation. Proc. Fla. State Hort. Soc. 103:88-91.

Snyder, R.L., B.J. Lanini, D.A. Shaw, and W.O. Pruitt. 1987. Using reference evapotranspiration $\left(\mathrm{ET}_{\mathrm{o}}\right)$ and crop coefficients to estimate crop evapotranspiration $\left(\mathrm{ET}_{0}\right)$ for agronomic crops, grasses and vegetable crops. Univ. of Calif. Coop. Ext. Lflt. 21427. 